\title{
Sex Pheromone of the Rare Click Beetle Betarmon bisbimaculatus
}

\author{
Christian König $^{1,2} \cdot$ Alexander Szallies $^{3} \cdot$ Johannes L. M. Steidle $^{1} \cdot$ Till Tolasch $^{1}$
}

Received: 23 September 2015 / Revised: 23 November 2015 / Accepted: 29 November 2015 / Published online: 23 December 2015

(C) Springer Science+Business Media New York 2015

\begin{abstract}
The click beetle Betarmon bisbimaculatus (Fabricius, 1803) (Coleoptera: Elateridae) has a scattered distribution throughout a large area in Europe and the near East. Due to its scarcity, little is known about the ecology, biology, and development of this peculiar species. Here, we studied the composition of the female-released sex pheromone of $B$. bisbimaculatus. Neryl hexanoate, neryl octanoate, and neryl decanoate, in a ratio of approximately $3: 1: 6$, were the only volatile compounds present in the extracts of pheromone glands. A synthetic mixture of all three compounds in the natural ratio was highly attractive to males in field traps. When the compounds were tested individually, only traps baited with neryl hexanoate were attractive, but they caught only a sixth of the males compared to the mixture. Based on the similarity of their sex pheromones, we propose that the tribe Pomachiliini with B. bisbimaculatus is closely related to the tribe Agriotini. This study shows the potential of sex pheromone studies for monitoring of rare and threatened insects as well as for elucidating phylogenetic relationships.
\end{abstract}

Keywords Neryl esters $\cdot$ Monitoring $\cdot$ Chemosystematics . Elaterinae · Pomachiliini

Christian König

Koenig@uni-hohenheim.de

1 Universität Hohenheim, Institut für Zoologie, Tierökologie 220c, Garbenstraße 30, D-70593 Stuttgart, Germany

2 Staatliches Museum für Naturkunde, Entomologische Abteilung, Rosenstein 1, D-70191 Stuttgart, Germany

3 Institut für Umwelt und Natürliche Ressourcen IUNR, Zürcher Hochschule für Angewandte Wissenschaften ZHAW, CH-8820 Wädenswil, Switzerland

\section{Introduction}

Betarmon bisbimaculatus (Fabricius, 1803) is a click beetle species of the tribe Pomachiliini Candèze (Coleoptera: Elateridae: Elaterinae) which is scarce (Reitter 1870, 1911) and occurring very locally (Horion 1953) throughout its entire distribution area, which ranges from the near East to N.W. Spain. In Red Data Books, the species is classified throughout its whole range as endangered (e.g., Germany: Geiser 1998), critically endangered (e.g., Carpathians: Witkowski et al. 2003), or even extinct (e. g., Sachsen-Anhalt: Dietze 2004). In the State of Baden-Württemberg (Southwest Germany), where our investigations were carried out, only two records were confirmed between 1950 and 2000 (Frank and Konzelmann 2002), the first of them by one of us (A.S.) on August 8th 1998 using an automobile-mounted sweep net.

The comparatively small beetles $(4-6 \mathrm{~mm})$ can be distinguished easily from similar sized species like Dalopius marginatus (Linnaeus, 1758) or Agriotes acuminatus (Stephens, 1830) by their unique, two-colored pattern of the pronotum and elytra (Fig. 1). The larva was first described by Dolin (1978), and can be separated from similar wireworms by the shape of the mandibles and the big mastoid bristle bearing pores at the tip of the ninth abdominal segment (Klausnitzer 1994). Due to its rarity, little is known about the ecology, biology, and development. Adults were found typically on wetlands or riversides with Salix L. and Populus L. (Horion 1953; Laibner 2000; Lohse 1979; Redtenbacher 1872; Reitter 1911) where they are active mainly in the afternoon during the flight period between June and July (Lohse 1979).

Here, we report on the identification, synthesis, and field testing of the female-produced sex pheromone. This should enable the development of a more specific and effective collection method to monitor the beetles in studies on natural 


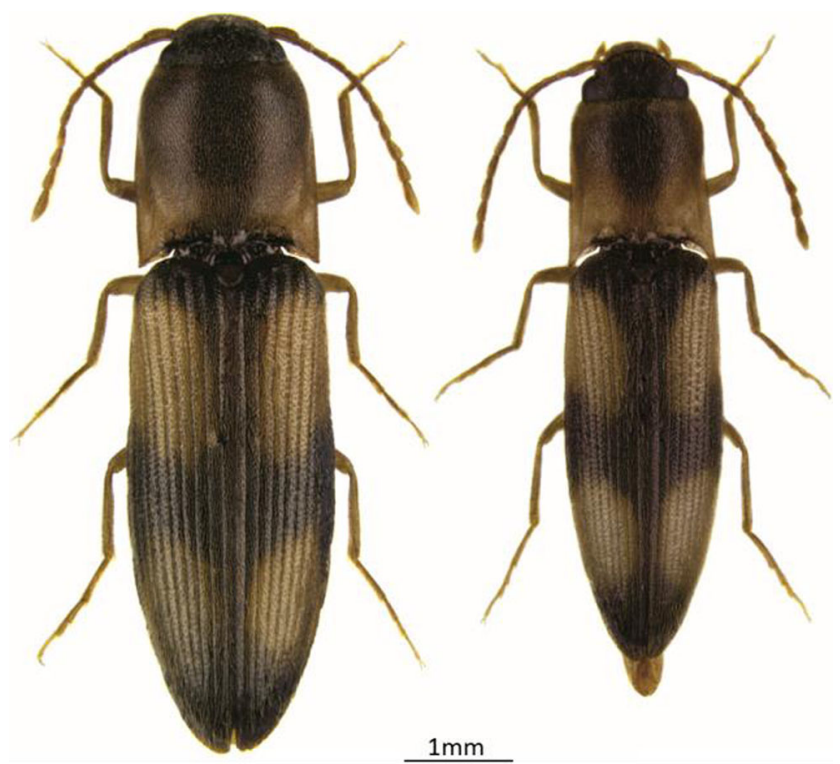

Fig. 1 Female and male of Betarmon bisbimaculatus (Fabricius, 1803) with their characteristic yellow spots at base and before apex on each elytron and the transition from reddish brown to yellow on the pronotum

conservation or ecology, as we found the synthetic pheromone blend to be highly attractive to swarming males.

\section{Methods and Materials}

Insects Adult beetles ( 12 males/5 females) were collected on June 26th 2012 near Burkheim am Kaiserstuhl/ Baden-Württemberg/Germany. Using a beating tray, all beetles were collected from shrubs and trees (mainly Salix spp.) around a gravel quarry (N $48.091^{\circ}, \mathrm{E} 7.583^{\circ}$, WGS84) on the right bank of the river Rhine. Live adults were kept individually in $1.5 \mathrm{ml}$ Eppendorf tubes until they could be sexed under a stereomicroscope.

Extracts The paired pheromone reservoirs of individual live females were collected intact by forcibly extruding the ovipositor and placing them in $300 \mu \mathrm{l}$ of $\mathrm{CH}_{2} \mathrm{Cl}_{2}$. Extracts were stored at $-20^{\circ} \mathrm{C}$ until analysis.

Chemical Analyses Analyses of natural extracts were carried out by coupled gas chromatography-mass spectrometry (GC/MS) on a $6890 \mathrm{GC} / 5973 \mathrm{~N}$ MSD quadrupole instrument (Agilent Technologies, Santa Clara, CA, USA) in EI mode at $70 \mathrm{eV}, 230{ }^{\circ} \mathrm{C}$. Compounds were separated with an HP5-MS fused silica capillary column $(30 \mathrm{~m} \times 0.25 \mathrm{~mm}$ i.d., $0.25 \mu \mathrm{m}$ film thickness; Agilent), with oven temperature starting at $60{ }^{\circ} \mathrm{C}$ for $3 \mathrm{~min}$, then increased to $300{ }^{\circ} \mathrm{C}$ at $3{ }^{\circ} \mathrm{C}$. $\mathrm{min}^{-1}$. The carrier gas was helium with a flow of $1.2 \mathrm{ml} \cdot \mathrm{min}^{-1}$. Retention indices (RI) for compounds were determined by comparing retention times with those of a homologous series of $n$-alkanes $\left(\mathrm{C}_{8}-\mathrm{C}_{30}\right)$ analyzed under the same conditions. Nuclear magnetic resonance (NMR) spectra of synthetic compounds were recorded with a Bruker DRX500 instrument (Bruker, Rheinstetten, Germany). Compounds were identified by comparison of mass spectra and retention indices with those of authentic samples.

Chemical Syntheses Chemicals and solvents were purchased from Sigma-Aldrich or Merck and were of highest purity available. Purification of synthetic products was carried out by flash chromatography on silica gel (silica 32-63, $60 \AA$, ICN-Biomedicals, Eschwege, Germany) at 1.3 bar using mixtures of ethyl acetate and hexane. Conversion of nerol to the corresponding esters was achieved by employing the appropriate acyl chlorides according to known methods (Tóth et al. 2003). Structures of all compounds synthesized are shown in Fig. 2. All compounds have been identified previously from other click beetle species (König et al. 2015; Tolasch et al. 2013; Tóth 2013).

Bait Dispensers and Field Tests Dispensers were prepared as described earlier (Tolasch et al. 2007) from $0.2 \mathrm{ml} \mathrm{PCR} \mathrm{tubes}$ (ThermoTube $^{\mathrm{TM}}$, Peqlab, Germany) that had been pierced with an insect pin $(0.5 \mathrm{~mm}$ diam. $)$ at the front side, $2 \mathrm{~mm}$ below the lid. The following mixtures of synthetic chemicals were placed into the tubes. Lure A: Neryl hexanoate (1), $3 \mathrm{mg}$. Lure B: Neryl octanoate (2), $1 \mathrm{mg}$. Lure C: Neryl decanoate (3), $6 \mathrm{mg}$. Lure D: $3 \mathrm{mg} \mathbf{1}+1 \mathrm{mg} \mathbf{2}+6 \mathrm{mg} \mathrm{3}$, resembling the natural ratio of these compounds found in the glands.

Under laboratory conditions, the dispensers had a stable mean release rate of approximately $8-10 \mu \mathrm{g}$ per day, regardless of the amount in the tubes (Tolasch et al. 2010). PCR tubes with lures were placed in funnel traps as described earlier (Tolasch et al. 2007). Each collecting bottle was filled with brine $(200 \mathrm{ml})$ to preserve the beetles and minimize the possible attraction of further individuals to those already captured. Traps were grouped in sets, each set consisting of four traps with the test substances (lures $\mathbf{A}, \mathbf{B}, \mathbf{C}$, and $\mathbf{D}$ ) and one unbaited control trap. Traps were suspended ca. 1.5-2.0 m above the ground on tree
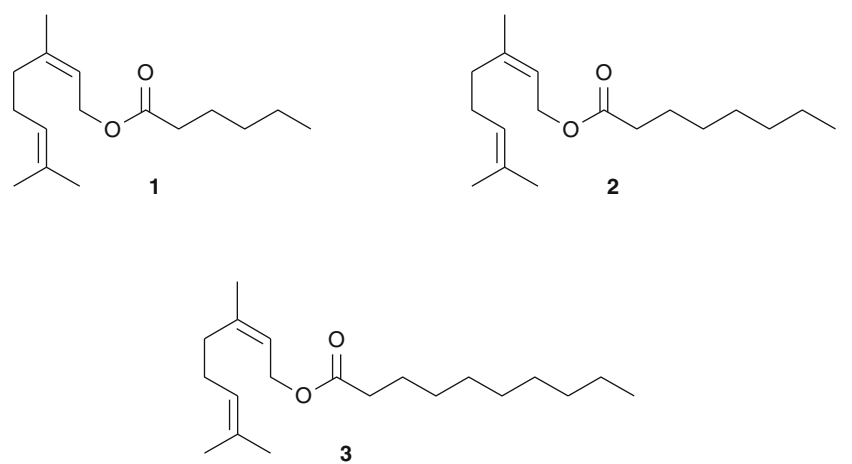

Fig. 2 Compounds identified from pheromone gland extracts of female Betarmon bisbimaculatus: Neryl hexanoate (1), neryl octanoate (2), and neryl decanoate (3) 
branches. The distance between traps within one set was about $5 \mathrm{~m}$, while the distance between the sets was at least $30 \mathrm{~m}$.

Field bioassays were performed from 25 June to 23 July 2014 near Burkheim am Kaiserstuhl/Baden-Württemberg/ Germany along the river Rhine next to a gravel quarry. The traps were checked every fortnight when captured beetles were removed and the brine was replaced. The numbers of male beetles were compared between traps by the Wilcoxon matched-pairs test using Statistica 6.1 (StatSoft, Tulsa, USA). Thirty traps were grouped into six sets in the first two weeks, fifty-four traps grouped into nine sets in the second two weeks $(N=15)$.

\section{Results}

Chemical Analyses GC/MS analysis of gland extracts of four females of B. bisbimaculatus revealed three compounds present in all gland extracts in a ratio of approximately $3: 1: 6$ (Fig. 3). These were identified by comparison of GC retention times and mass spectra with those of synthetic samples as neryl hexanoate (1) (median $27.8 \%$, min $21.1 \%$, max $42.0 \%$ ), eluting at $38.0 \mathrm{~min}$ (RI 1731), neryl octanoate (2) (median $9.3 \%$, min $7.3 \%$, max $11.5 \%$ ), eluting at $44.6 \mathrm{~min}$ (RI 1926), and neryl decanoate (3) (median $62.7 \%$, min $50.6 \%$, max $67.9 \%$ ), eluting at 50.7 min (RI 2124) under the conditions described.

Field Trapping Experiments The field test revealed a strong and highly significant attractiveness of the traps baited with the mixture (lure $\mathbf{D}, 187$ males) compared to the control traps and the traps with the single compounds $(P<0.001$, compared to all other traps) (Fig. 4). From the single compound traps, only those with neryl hexanoate $(\mathbf{1}$, lure $\mathbf{A})$ were attractive $(P<0.001)$, capturing a total of 29 males. In traps with lure $\mathbf{2}$ and lure $\mathbf{3}$ as well as in the control traps no beetles were found.

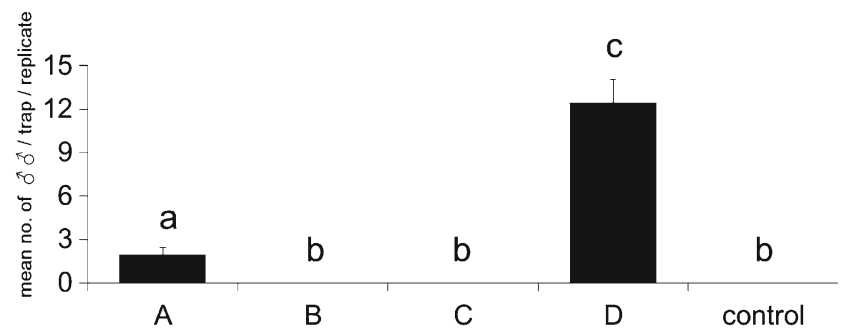

Fig. 4 Mean (+SE) trap catches/trap/replicate $(N=15)$ of male Betarmon bisbimaculatus near Burkheim am Kaiserstuhl/Baden-Württemberg/ Germany. Columns with different lowercase letters are significantly different at $P<0.001$ (Wilcoxon-matched pairs-test)

\section{Discussion}

Our chemical analyses revealed the presence of neryl hexanoate (1), neryl octanoate (2), and neryl decanoate (3) in a 3:1:6 ratio as the sole compounds in the pheromone glands of female $B$. bisbimaculatus. A mixture of all three compounds in the natural ratio was highly attractive to conspecific males. In contrast, only neryl hexanoate was attractive as a single compound, albeit to a much lesser degree than the mixture $(<20 \%)$. This demonstrates a strong synergistic effect of $\mathbf{2}$ and/or $\mathbf{3}$. However, it remains to be studied if this synergism is based on both compounds or if only one of them is sufficient to generate the maximum attractive effect.

Based on the female produced sex pheromone structures known to date, the subfamily Elaterinae has been divided into two groups, which fits the current classification (Tolasch et al. 2007). Members of the tribe Elaterini produce esters of iso-methyl branched esters with acids having even numbers of carbon atoms, such as 7-methyloctyl (Z)-4-decenoate in Elater ferrugineus (Tolasch et al. 2007). The closely related Sericus spp. also use compounds of this type as sex pheromones (Tolasch, unpubl.).

In the tribe Agriotini, which contains the economically important Agriotes species, several esters of acyclic, isoprenoid alcohols with acids having even numbers of carbon atoms
Fig. 3 Gas chromatogram (total ion current) of a pheromone gland extract of a single Betarmon bisbimaculatus female.

Compound numbers correspond to the text and Fig. 2

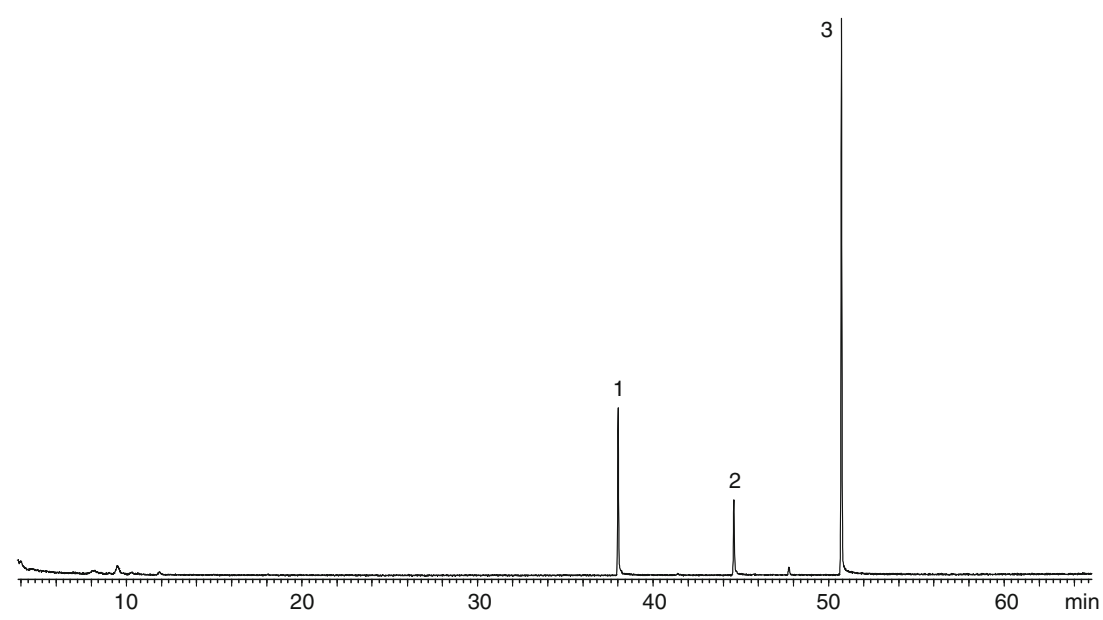


(two to eight) have been identified as pheromone components. A typical example is $(E, E)$-farnesyl butyrate, which, together with geranyl butyrate, is the major component of the sex pheromone of Agriotes brevis Candeze (Tóth et al. 2002).

Betarmon bisbimaculatus and the sister genus Idolus (see König et al. 2015; Tolasch et al. 2013) are currently placed into a third tribe, the Pomachiliini (Laibner 2000). The results described here indicate that, from the chemotaxonomical point of view, the Pomachiliini and the Agriotini are closely related. This also is evident from the larval morphology where Idolus Desbrochers and Betarmon Kiesenwetter are grouped together with the Agriotini (Dolin 1978; Klausnitzer 1994). Additional molecular phylogenetic investigations including as many members of both tribes as possible would be necessary to confirm the Pomachiliini as a distinct and monophyletic tribe.

The use of sex pheromones has turned out to be an extremely powerful method in monitoring scarce and endangered insect species. Our identification of 7-methyloctyl-(Z)-(4)-decenoate as sex pheromone of female E. ferrugineus (von Fragstein 2006; Tolasch et al. 2007), for example, has resulted in a number of studies concerning the distribution and abundance of this species (e.g., Tolasch et al. 2007 for south Germany; Zauli et al. 2014 for central Italy; Thomaes et al. 2015 for Belgium; Oleksa et al. 2015 and Kadej et al. 2015 for Poland; Svensson et al. 2012, Musa et al. 2013 and Andersson et al. 2014 for Sweden).

For B. bisbimaculatus, pheromone traps should also be a useful method for research and monitoring programs. In two collecting trips to Burkheim am Kaiserstuhl, five experienced field entomologists could catch only five female $B$. bisbimaculatus in total using conventional methods, even though the focus was exclusively on this species. With pheromone traps, almost 100 beetles were collected in the first two weeks of the study at the same location.

Acknowledgments We thank the Hermann Uhl e.K., especially Mr. Barz and Mr. Schamberger, for their permit and local support. We thank Christoph Scheck and Lea Boettinger for support in fieldwork.

\section{References}

Andersson K, Bergman K-O, Andersson F, Hedenström E, Jansson N, Burman J, Winde I, Larsson MC, Milberg P (2014) High-accuracy sampling of saproxylic diversity indicators at regional scales with pheromones: the case of Elater ferrugineus (Coleoptera, Elateridae). Biol Conserv 171:156-166

Dietze R (2004) Rote Liste der Schnellkäfer (Coleoptera: Elateridae) des Landes Sachsen-Anhalt. Berichte des Landesamtes für Umweltschutz Sachsen Anhalt 39:318-322

Dolin WG (1978) Opredelitel licinok zukov - scelkunov fauny SSSR. Urozaj, Kiew
Frank J, Konzelmann E (2002) Die Käfer Baden-Württembergs 1950 2000. Landesanstalt für Umweltschutz Baden-Württemberg. Naturschutz-Praxis, Artenschutz 6. 1. Auflage. ISBN 3-88251281-4

Geiser R (1998) Rote liste der Käfer (Coleoptera). In: Binot M, Bless R, Boye P, Gruttke H, Gladitsch S (eds) Rote Liste gefährdeter Tiere Deutschlands. Bundesamt für Naturschutz, Bonn, pp. 168-230

Horion A (1953): Faunistik der mitteleuropäischen Käfer, Bd. 3: Malacodermata, Sternoxia (Elateridae bis Throscidae). Entomol Arb Mus Frey, Sonderband, Tutzing

Kadej M, Zając K, Ruta R, Gutowski JM, Tarnawski D, Smolis A, Olbrycht T, Malkiewicz A, Myśków E, Larsson MC, Andersson F, Hedenström E (2015) Sex pheromones as a tool to overcome the wallacean shortfall in conservation biology: a case of Elater ferrugineus Linnaeus, 1758 (Coleoptera: Elateridae). J Insect Conserv 19:25-32

Klausnitzer B (1994) 42. Familie: Elateridae. In: Die Larven der Käfer Mitteleuropas. 2. Band. Myxophaga, Polyphaga. Teil 1. Goecke \& Evers, Krefeld, pp 118-189

König C, Steidle JML, Tolasch T (2015) Decrypting cryptic click beetle species by analysis of sex pheromones. J Chem Ecol 41:740-745

Laibner S (2000) In: Elateridae of the Czech and Slovak republics. Kabourek, Zlín, pp. 180-183

Lohse GA (1979) 34. Familie: Elateridae. In: Freude H, Harde K, Lohse GA (eds) Die Käfer Mitteleuropas, Band 6: Diversicornia. Goecke \& Evers, Krefeld, pp. 103-186

Musa N, Andersson K, Burman J, Andersson F, Hedenström E, Jansson N, Paltto H, Westerberg L, Winde I, Larsson MC, Bergman K-O, Milberg P (2013) Using sex pheromone and a multi-scale approach to predict the distribution of a rare saproxylic beetle. PLoS One 8: e66149

Oleksa A, Chybicki IJ, Larsson MC, Svensson GP, Gawroński R (2015) Rural avenues as dispersal corridors for the vulnerable saproxylic beetle Elater ferrugineus in a fragmented agricultural landscape. $\mathrm{J}$ Insect Conserv 19:567-580

Redtenbacher L (1872) Fauna Austriaca. Die Käfer. Dritte, gänzlich umgearbeitete und bedeutend vermehrte Auflage. Carl Gerold's Sohn, Wien, pp. 534-535

Reitter E (1870) Uebersicht der Käfer-Fauna von Mähren und Schlesien. Sonderabdruck aus dem VIII. Bande der Verhandlungen des naturforschenden Vereins in Brünn, Brünn, p. 103

Reitter E (1911) In: Fauna Germanica. Die Käfer des Deutschen Reiches. III. Band. K.G Lutz' Verlag, Stuttgart, p 235

Svensson GP, Liedtke C, Hedenström E, Breistein P, Bång J, Larsson MC (2012) Chemical ecology and insect conservation: optimising pheromone-based monitoring of the threatened saproxylic click beetle Elater ferrugineus. J Insect Conserv 16:549-555

Thomaes A, Crevecoeur L, Wijnants M (2015) Tree cavity beetles in Haspengouw and pays De herve: Crepidophorus mutilatus (Elateridae) new for the Belgian fauna and rediscovery of Gnorimus variabilis (Cetoniidae) (Insecta: Coleoptera). Bull Soc Roy Belg Entomol 151:40-51

Tolasch T, von Fragstein M, Steidle JLM (2007) Sex pheromone of Elater ferrugineus L. (Coleoptera: Elateridae). J Chem Ecol 33:2156-2166

Tolasch T, von Fragstein M, Steidle JLM (2010) Sex pheromone of Agriotes acuminatus (Stephens, 1830) (Coleoptera: Elateridae). J Chem Ecol 36:314-318

Tolasch T, König C, von Fragstein M, Steidle JLM (2013) Identification of the sex pheromone of Idolus picipennis (Bach, 1852) revealed the presence of a cryptic sibling species. J Chem Ecol 39:1433-1440

Tóth M (2013) Pheromones and attractants of click beetles: an overview. J. Pestic Sci 86:3-17

Tóth M, Furlan L, Yausinin VG, Ujvary I, Szarukán I, Imrei Z, Subchev M, Tolasch T, Fancke W (2002) Identification of sex pheromone composition of click beetle Agriotes brevis candeze. J Chem Ecol 28:1641-1652 
Tóth M, Furlan L, Yatsynin VG, Ujváry I, Szarukán I, Imrei Z, Tolasch T, Francke W, Jossi W (2003) Identification of pheromones and optimization of bait composition for click beetles pests (Coleoptera: Elateridae) in central and western Europe. Pest Manag Sci 59:417-425

von Fragstein M (2006) Sexualpheromone bei Schnellkäfern (Elateridae). Diploma thesis, University of Hohenheim
Witkowski ZJ, Król W, Solarz W (eds) (2003) Carpathian list of endangered species. WWF and Institute of Nature Conservation, Polish Academy of Sciences, Vienna-Krakow. ISBN 83-918914-0-2

Zauli A, Chiari S, Hedenstrom E, Svensson GP, Carpaneto GM (2014) Using odour traps for population monitoring and dispersal analysis of the threatened saproxylic beetles Osmoderma eremita and Elater ferrugineus in central Italy. J Insect Conserv 18:801-813 